\title{
Optimization of Tower Crane in Mega Construction Project- Case Study
}

\author{
Mr. K. D Patil ${ }^{1}$, Prof. P.P Bhangale ${ }^{2}$ \\ M.E, Civil Engineering, S.S.G.B.COE \& Tech., Bhusawal, India ${ }^{1}$ \\ Professor, Civil Engineering, S.S.G.B.COE \& Tech., Bhusawal, India ${ }^{2}$
}

\begin{abstract}
The crane has become the inseparable part of the construction industries there are numbers of cranes. But in India tower crane is been use generally and if we use it properly we can complete our task within time period but there factor which affect the working of tower cranes and leads to delay in work and hamper the economy of the project. So to overcome it we have to optimize the use of tower crane by reducing the hurdle in it. So the factor which causes obstruction in utilization of tower crane is identified which environmental factor, safety management factor, Human factor and project condition this are the four main factor which affect the crane working and there many sub factor too. To find it out we have done the questionnaire survey. And mark the response on 1 to 5 scales and then we have done the analysis on it. In this study we identified the factor which affect the efficiency of the tower crane and rank them accordingly.
\end{abstract}

Keywords: Environmental Factor, Safety Management Factor, Human Factor and Project Condition, Tower Crane.

\section{INTRODUCTION}

Cranes are considered as the centrepiece of construction equipment in building projects. They play a key role in transporting a variety of materials vertically and horizontally. The efficiency of cranes largely depends on their type, number and location. The cost of the equipment varies from 10 to $30 \%$ of the total cost of the project, depending upon the extend of mechanization. In modern fully mechanized project the cost of the equipment goes up to $30 \%$ proper planning, selection, procurement, installation, operation, maintenance and equipment replacement policy plays an important role in management for the successful completion of project. With the growing use of machinery it has become necessary for construction engineer to be thoroughly familiar with the construction application and upkeep of the wide range of modern equipment. This study purports to explore the factor which affects the efficiency of the tower crane.

\section{NECESSITY OF UTILIZATION OF CRANES IN MEGA CONSTRUCTION PROJECT}

High-rise buildings are the essential form of building structure constructed extensively in urban areas, in particular, in the heart of the commercial zones of metropolitan cities or in densely populated areas. Scarcity of land supply encourages the construction of high-rise buildings. At this time it is known by all, that Mumbai is occupying approximately 20.5 million populations over $603.4 \mathrm{~km} 2$ Area and hence, highly populated and densified metropolitan city in India an 4th in World. To occupy such Large numbers of population it becomes necessary to move towards sky i.e. vertically. Hence now days it is observed that, the Residential buildings of 40 to 45 storeys became very common in Mumbai. So the developers are moving towards the skyscrapers of around 70 to 120 storey's to accommodate lot of population and to earn very nice figure of returns on their investments in short period of time.

\section{TO STUDY PLANNING OF TOWER CRANES FOR CONSTRUCTION PROJECT}

- Weight and radius of the heaviest lift and the farthest pick.

The boom/jib length and tail swing of the crane.

- Consider how jib length and tail swing relate to fixed obstructions on or near the jobsite such as high power lines, buildings, bridges or future obstructions such as cranes or equipment to be used or erected on the project.

- Check for underground obstructions such as septic tanks, underground power and gas lines and soil conditions before determining the type or size of foundation.

- Noise and environmental restrictions. Most applications tolerate both diesel and electrically powered machines. In an enclosed environment, however, electric power is best.

\section{METHODOLOGY}

Generally methodology can be considered more than simply the method intends to use to collect data. It is often necessary to include a consideration of the concepts and theories which underline the methods. Theoretical analysis of the method and applied it to a field study. This study presents the main factor affecting the performance of construction projects and from literature review and past 
Vol. 4, Issue 2, February 2017

studies. It was obtained that there were different direction and methodologies used in order to achieve the required target the goals and objective. Some of previous studies focused on factor affecting the performance of tower crane with in general view, other studies concentrated on one or two directions such as cost, time and quality performance, other studies focused on measurement of tower crane performance. The differentiation of directions and goals of topic as shown previously, required different methodologies. Main methodologies obtain from literature review were: questionnaire survey and case study.

To determine the most significant key performance indicators of construction projects. The RII method has been adopted by many researchers. The relative importance index is computed as:

$\mathrm{RII}=\sum \mathrm{W} /(\mathrm{A} * \mathrm{~N})$

Where, $\mathrm{W}$ is the weight given to each factor by the respondents \& ranges from 1 to 5 ,

$\mathrm{A}=$ the highest weight $=5$,

$\mathrm{N}=$ the total number of respondents

Analysed the practices concerning in order to know the main practical problems of tower crane and then to formulate recommendations to improve efficiency of tower cranes on construction sites.

Table No.1 Showing Ordinal/Likert Scale Used for Data Measurement.

\begin{tabular}{|c|c|c|c|c|c|}
\hline Item & $\begin{array}{c}\text { Very } \\
\text { High } \\
\text { Imp. }\end{array}$ & $\begin{array}{c}\text { High } \\
\text { Imp }\end{array}$ & $\begin{array}{c}\text { Medium } \\
\text { Imp. }\end{array}$ & $\begin{array}{c}\text { Low } \\
\text { Imp. }\end{array}$ & $\begin{array}{c}\text { Very } \\
\text { Low } \\
\text { Imp. }\end{array}$ \\
\hline Scale & 5 & 4 & 3 & 2 & 1 \\
\hline
\end{tabular}

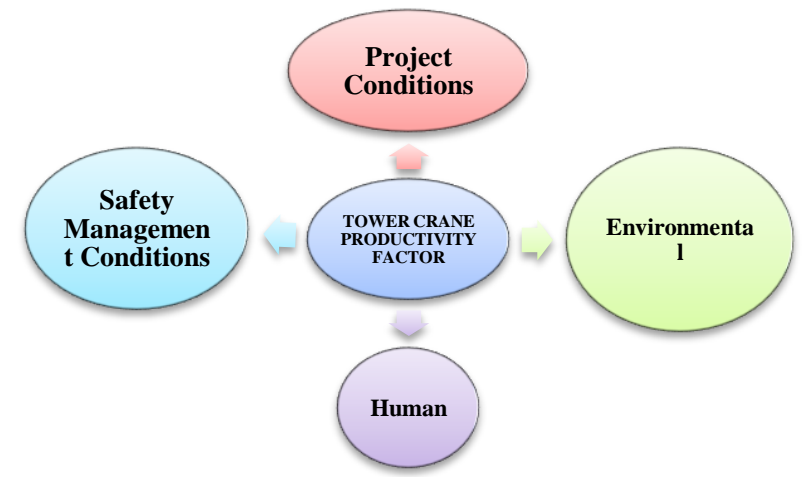

Figure. No.1 Showing Framework for Productivity Factors in Construction Project of Tower Crane

\section{Environmental Factors}

This group consists of factors which are wind velocity, sand storm, visibility, seasonal rain and temperature. These factors affect tower crane productivity, either positively or negatively in a natural way. At some site the conditions are worthy and at some sites the conditions do not support the site. This also affects the productivity of tower crane on construction projects.

\section{Safety Management Condition}

Safety is defined as the degree to which the general conditions promote the completion of a project without major accidents or injuries. The measurement of safety is mainly focused on the construction period as most accidents occur during this stage. Throughout the world, construction industry is known as one of the most hazardous activities. Thousands of people are killed and disabling injury annually in industrial accident. Construction workers worldwide have three times more chances of dying and two times of getting injured than any worker of other economic activity. There is no single measured of safety condition. Traditionally, the safety intensity is measured through injury statistic. The main purpose of measuring affect of safety on tower crane is to provide information on the progress and current status of strategies, processes and activities employed to control safety risks. Following are the sub factors related to safety management conditions of tower cranes.

\section{Human Factor}

Operator Proficiency- Operator proficiency is the foremost ingredient in determining safety level of crane work and surroundings. Objective measures of operator skills are:

1 Formal training and certification;

\section{Safety records.}

Experience is measured first and foremost by the number of crane-operating years but also by the variety e.g., crane types and models, project types and dimensions to which the operator has been exposed over the years.

\section{Project Condition}

Obstacles and Congested Site- With the aspiration of builders in urban areas to use the maximum land available for construction, sites in urban areas can become extremely crowded. Under such conditions, staging areas, various temporary facilities, equipment moving and operating on site, and adjacent buildings in close proximity, all constitute obstacles for crane work.

\section{Result and Analysis:- Example:}

Main Factor - Environmental factor.

Sub Factor- Wind Velocity.

According to evaluation sheet out of the entire 10 respondents 4 respondent have ranked the wind velocity factor as very highest i.e. 5. And 5 respondent have ranked it is as high importance i.e. 4, also 1 respondent have ranked it is as medium importance.

\section{Calculation-}

The summation of weightage $=4 * 5+5 * 4+1 * 3=43$

Now, $\mathrm{RII}=\sum \mathrm{W} /(\mathrm{A} * \mathrm{~N})$

Where, RII = Relative Importance Index,

$\mathrm{W}=$ Weight given to each factor by the respondents and ranges from 1 to $5=43$,

$\mathrm{A}=$ The highest weight $=5$,

$\mathrm{N}=$ The total number of respondents $=10$.

$\mathrm{RII}=43 /(5 * 10)=0.86$

Thus, the RII for wind velocity of tower crane factor equals to 0.86 . 
Vol. 4, Issue 2, February 2017

Table No.2 Factor Affecting the Productivity of the Tower Crane on Construction Projects

\begin{tabular}{|l|l|c|c|c|}
\hline Sr. No. & \multicolumn{1}{|c|}{ Factor } & RII & Factor Wise Rank & Over All Rank \\
\hline $\mathbf{1 . 0}$ & Environmental Factors & & & \\
\hline 1.1 & Wind velocity & 0.86 & 1 & 1 \\
\hline 1.2 & Weather & 0.34 & 6 & 11 \\
\hline 1.3 & Visibility & 0.56 & 3 & 4 \\
\hline 1.4 & Unforeseen heavy rain & 0.4 & 5 & 15 \\
\hline 1.5 & Temperature & 0.26 & 7 & 5 \\
\hline 1.6 & Seasonal rain & 0.52 & 4 & 3 \\
\hline 1.7 & Sand storm & 0.6 & 2 & \\
\hline
\end{tabular}

\begin{tabular}{|c|l|c|c|c|}
\hline $\begin{array}{l}\text { Sr. No } \\
\mathbf{2 . 0}\end{array}$ & \multicolumn{1}{|c|}{ Human Factors } & RII & $\begin{array}{c}\text { Factor Wise } \\
\text { Rank }\end{array}$ & $\begin{array}{c}\text { Over All } \\
\text { Rank }\end{array}$ \\
\hline 2.1 & Use of multiple languages & 0.5 & 2 & 6 \\
\hline 2.2 & Proficiency of the lifting supervisor & 0.22 & 6 & 17 \\
\hline 2.3 & Proficiency of signalman & 0.34 & 5 & 11 \\
\hline 2.4 & Proficiency of riggers & 0.76 & 1 & 2 \\
\hline 2.5 & Crane operator's license validity & 0.34 & 5 & 11 \\
\hline 2.6 & Crane operator's experience and proficiency & 0.46 & 3 & 7 \\
\hline 2.7 & Crane operator's behavioral patterns and mental capacity & 0.36 & 4 & 10 \\
\hline
\end{tabular}

\begin{tabular}{|c|l|c|c|c|}
\hline $\begin{array}{c}\text { Sr. No } \\
3.0\end{array}$ & \multicolumn{1}{|c|}{ Safety management condition } & RII & $\begin{array}{c}\text { Factor Wise } \\
\text { Rank }\end{array}$ & $\begin{array}{c}\text { Over All } \\
\text { Rank }\end{array}$ \\
\hline 3.1 & Tool box meeting & 0.1 & 13 & 23 \\
\hline 3.2 & Site layout as per safety standards & 0.06 & 15 & 25 \\
\hline 3.3 & Safety training programs for crane operators & 0.14 & 11 & 21 \\
\hline 3.4 & Safety training programs for signal man & 0.12 & 12 & 22 \\
\hline 3.5 & Safety measures during dismantling & 0.08 & 14 & 24 \\
\hline 3.6 & Regular inspection of lifting devices like slings. & 0.16 & 10 & 20 \\
\hline 3.7 & Provide personal protective equipment's (PPE) & 0.32 & 3 & 12 \\
\hline 3.8 & Preventive maintenance management & 0.3 & 4 & 13 \\
\hline 3.9 & Presence of health, safety and environment dept. & 0.46 & 1 & 7 \\
\hline 3.10 & Presence of safety engineers and stewarts & 0.08 & 14 & 24 \\
\hline 3.11 & Permits before starting of crane operations & 0.28 & 5 & 18 \\
\hline 3.12 & Organization's strict safety policy & 0.38 & 2 & 9 \\
\hline 3.13 & Inspection of crane by third party & 0.18 & 9 & 19 \\
\hline 3.14 & Crane inspection checklists & 0.24 & 6 & 16 \\
\hline 3.15 & Certified lifting supervisor & 0.22 & 7 & 17 \\
\hline 3.16 & Adequate lighting during night shift & 0.2 & 8 & 18 \\
\hline
\end{tabular}

\begin{tabular}{|c|l|c|c|c|}
\hline 4.0 & \multicolumn{1}{|c|}{ Project condition factors. } & RII & Factor Wise Rank & Over All Rank \\
\hline 4.1 & Type of load and rigging method & 0.2 & 5 & 18 \\
\hline 4.2 & Sight distance and angle & 0.24 & 4 & 16 \\
\hline 4.3 & Project supervision & 0.24 & 4 & 16 \\
\hline 4.4 & Project location & 0.12 & 9 & 22 \\
\hline 4.5 & Project duration & 0.08 & 11 & 24 \\
\hline 4.6 & Project cost & 0.1 & 10 & 23 \\
\hline 4.7 & Presence of power lines & 0.36 & 1 & 10 \\
\hline 4.8 & Presence of overlapping cranes & 0.32 & 2 & 12 \\
\hline 4.9 & Presence of obstacles on site & 0.16 & 7 & 20 \\
\hline 4.10 & Poor ground condition & 0.3 & 3 & 13 \\
\hline 4.11 & Operator aids & 0.18 & 6 & 19 \\
\hline 4.12 & Management condition & 0.16 & 7 & 20 \\
\hline 4.13 & Length of work shift & 0.14 & 8 & 21 \\
\hline 4.14 & Inconvenient work conditions in operator cabin & 0.2 & 5 & 18 \\
\hline 4.15 & Congestion in the project site & 0.18 & 6 & 19 \\
\hline
\end{tabular}


Table No.3 Shows Significant Tower Crane Productivity Factor

\begin{tabular}{|c|l|c|c|}
\hline Sr. No. & \multicolumn{1}{|c|}{ FACTOR } & RII & overall rank \\
\hline 1 & Wind velocity & 0.86 & 1 \\
\hline 2 & Proficiency of riggers & 0.76 & 2 \\
\hline 3 & Sand storm & 0.6 & 3 \\
\hline 4 & Visibility & 0.56 & 4 \\
\hline Sr. No. & & RII & overall rank \\
\hline 5 & Seasonal rain & 0.52 & 5 \\
\hline 6 & Use of multiple languages & 0.5 & 6 \\
\hline 7 & Crane operator's experience and proficiency & 0.46 & 7 \\
\hline 8 & Presence of health, safety and environment dept. & 0.46 & 7 \\
\hline 9 & Unforeseen heavy rain & 0.4 & 8 \\
\hline 10 & Organization's strict safety policy & 0.38 & 9 \\
\hline 11 & Crane operator's behavioral patterns & 0.36 & 10 \\
\hline 12 & Presence of power lines & 0.36 & 10 \\
\hline
\end{tabular}

Table No.4. Shows The Relative Importance Index

(RII) \& Rank of Major Group Affecting the Productivity of the Tower Crane

\begin{tabular}{|c|l|c|c|}
\hline $\begin{array}{c}\text { Sr. } \\
\text { No }\end{array}$ & \multicolumn{1}{|c|}{ Major Factors } & RII & Rank \\
\hline 1 & Environmental factor & 0.505 & 1 \\
\hline 2 & Human factor & 0.425 & 2 \\
\hline 3 & Safety management condition & 0.207 & 3 \\
\hline 4 & Project condition & 0.198 & 4 \\
\hline
\end{tabular}

Graph No. 1 Showing Environmental Factor



Graph No. 2 Showing Human Factor

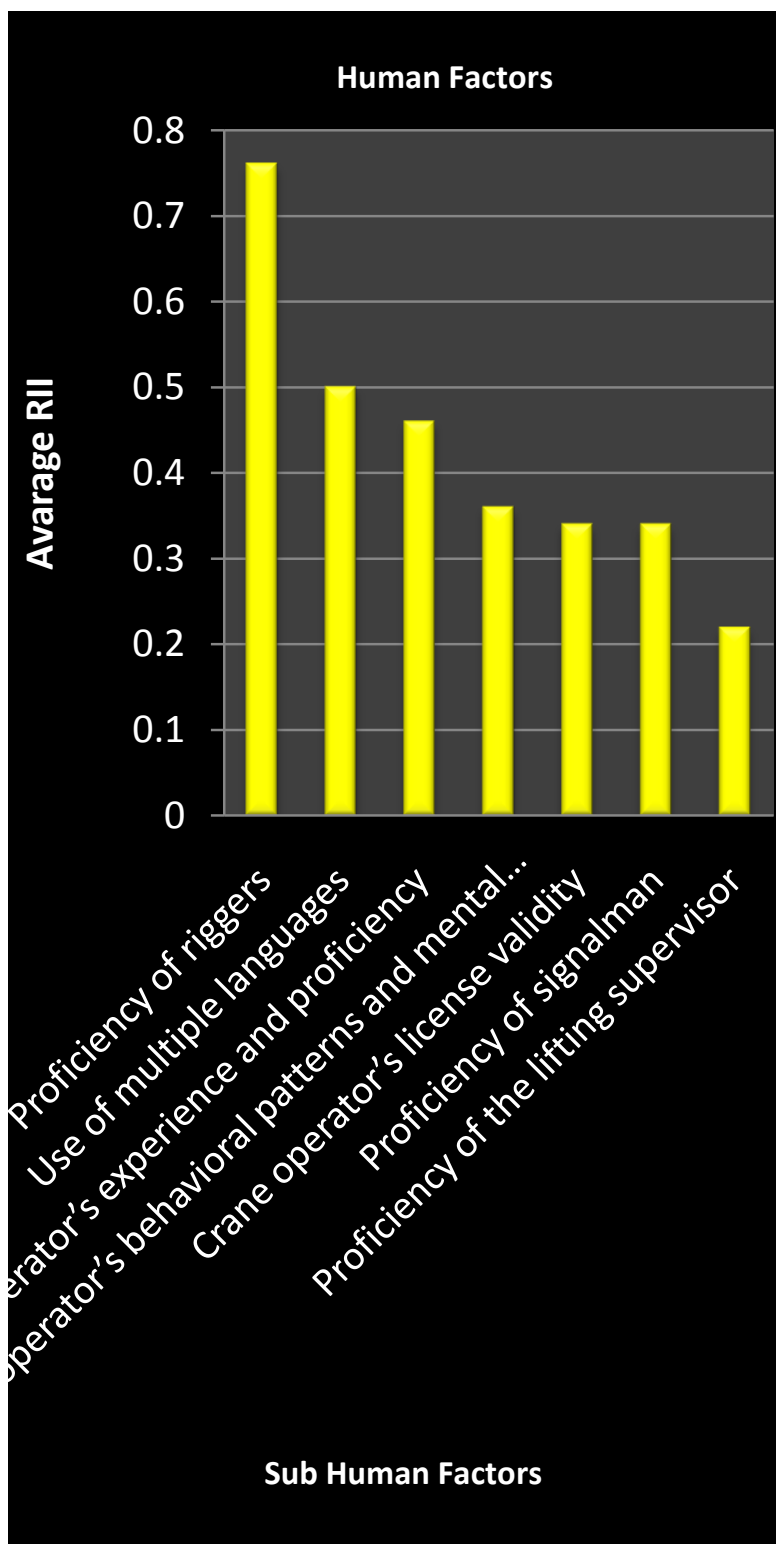


Graph No. 3 Showing Safety Factors

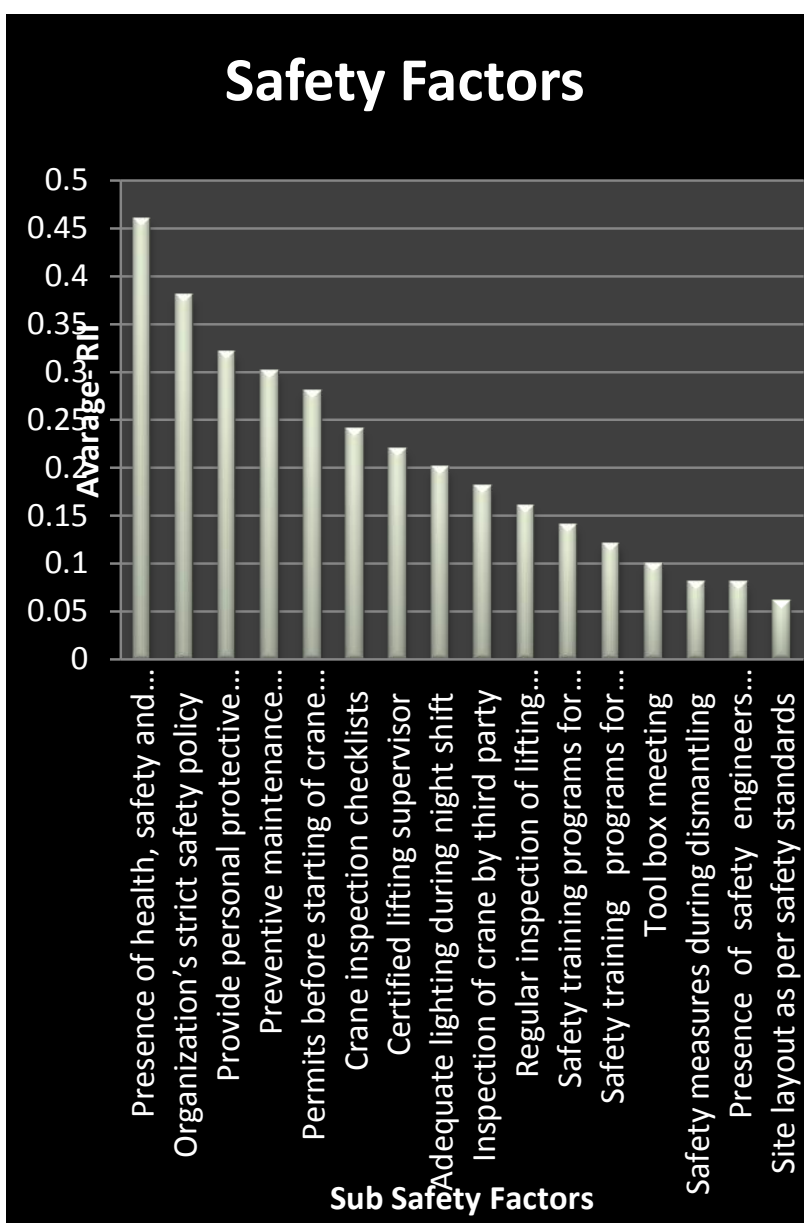

Graph No. 4 Showing Project condition Factors

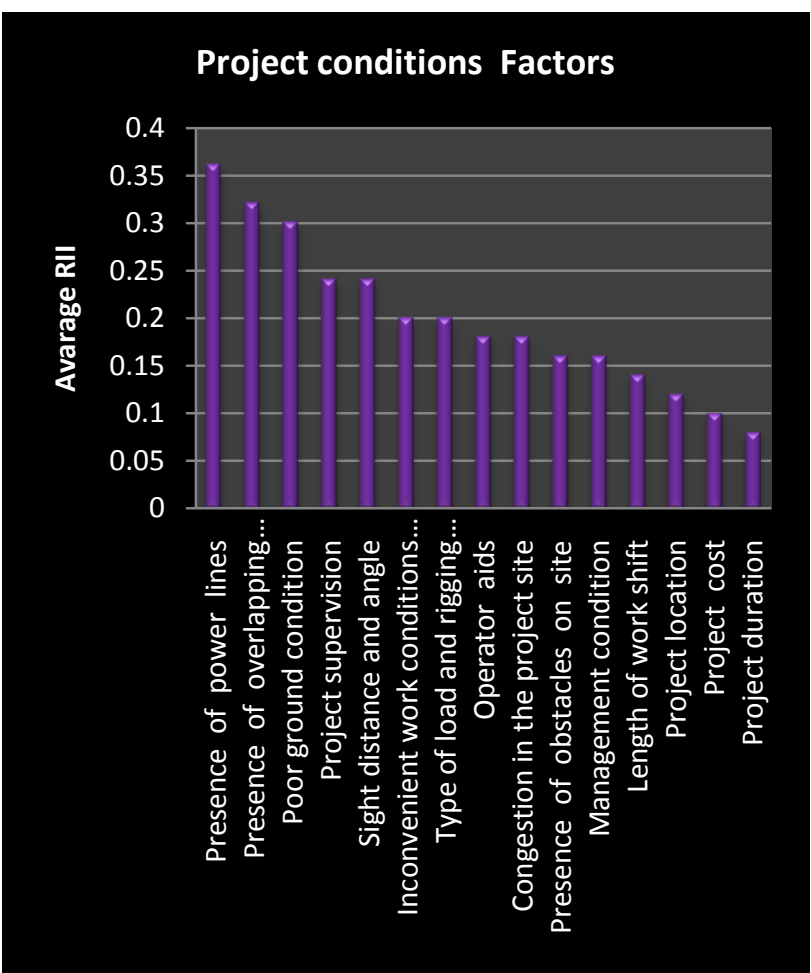

\section{CONCLUSIONS}

According to the analysis of tower crane operations Environmental Factors appears to be the most important factor affecting the tower crane operations followed by Human Factors, Safety Management Conditions and Project Conditions. The average relative importance index (RII) of these factors is $0.505,0.425,0.207$ and 0.198 respectively.

1 The environmental factors, wind velocity, occurrence of sand storm, visibility during the tower crane operations, seasonal and unforeseen rains, adverse weather conditions and temperature need to be taken care for smooth and safe tower crane operations. This factor affects $37 \%$ to site.

2 The human factors, the project authorities should focus more on the proficiency of the riggers, language and communication problem, crane operator's efficiency, validity of the license of the crane operator, proficiency of the signalman and proficiency of lifting supervisor.

3 Safety management condition factors like presence of safety department, organization's strict safety policy, providing PPE, precautions against failure of structural components, preventive maintenance and permits before starting of crane operations appear to be most important.

\section{REFERENCES}

[1] Amir Zavichi-(2012)-Creating Automated Crane Work Plans Using Real Time Operational Data and Predictive Analysis. Construction research congress 2012@ ASCE pp-321-330.

[2] Malak Al Hattab et-al-Optimizing Joint Operation of Two Tower Cranes Through Look-Ahead Planning And Process Simulation. Proceedings IGLC-22, June 2014 | Oslo, Norway pp-535-546.

[3] Aviad Shapira - Cranes for Building Construction Projects. Journal of Construction Engineering and Management, Vol. 133, No. 9, September 1, 2007. CASCE, ISSN 0733-9364/2007/9-pp-690-700.

[4] Md. Shafiul Hasan-(2013)-Decision Support System for Crane Selection and Location Optimization on Construction Sites. Thesis, University of Alberta PP-1-189.

[5] Aviad Shapira et-al- Identification and Analysis of Factors Affecting Safety on Construction Sites with Tower Cranes. Journal of Construction Engineering and Management, Vol. 135, No. 1, January 1, 2009. CASCE,ISSN 0733-9364/2009/1-pp-24-33.

[6] Donghoon Lee- Analysis of Operation Efficiency of Tower Crane in Form Work Construction for Multi-Family Housing. National Research Foundation of Korea (NRF)grant funded by the Korea government No.2011-0001031-pp-28-35.

[7] S. K. Subramaniam .Machine efficiency and man power utilization on production lines PP-978-960-474-053-6.

[8] M. Waris- Criteria for the selection of sustainable onsite construction equipment International Journal of Sustainable Built Environment (2014) 3, pp-96-110.

[9] H. Abdel-Khalek- A Computer-based Model for Optimizing the Location of Single Tower Crane in Construction Sites. International Journal of Engineering Science and Innovative Technology Volume 2, Issue 2, March 2013-pp-201-220.

[10] Shihchung -"Planning and visualization for automated robotic crane erection Processes in construction" Automation in Construction 15 (2006) pp-398 - 414

[11] C. Huang, C.K. Wong -“'Optimization of tower crane and material supply locations in a high-rise building site by mixed-integer linear programming" Automation in Construction 20 (2011) pp-571-580 13 December 2010 
[12] Aviad Shapira - "Integrative Model for Quantitative Evaluation of Safety on Construction Sites with Tower Cranes" Journal of Construction Engineering and Management, Vol. 138, No. 11, November 1, 2012. ( ) ASCE page no 1281-1293.

[13] T. G. Mara - "Effects of a Construction Tower Crane on the Wind Loading of a High-Rise Building" Journal of Structural Engineering, Vol. 136, No. 11, November 1, 2010. @ASCE, ISSN 0733-9445/2010/11-pp-1453-1460.

[14] Heng Li - "Multiuser Virtual Safety Training System for Tower Crane Dismantlement". Journal of Computing in Civil Engineering, Vol. 26, No. 5, September 1, 2012. C) ASCE, ISSN0887-3801/ 2012/5-pp-638-647.

[15] Yanming $\mathrm{Li}$ - "Integrating field data and 3D simulation for tower crane activity monitoring and alarming". Automation in Construction 27 (2012) pp- 111-119.

[16] Richard L. Neitzel, Noah S. Seixas, and Kyle K. Ren - "A Review of Crane Safety in the Construction Industry". Applied Occupational and Environmental Hygiene Volume 16(12): pp1106-1117, 2001

[17] Shapiro H. I., Shapiro J. P., Shapiro L. K. 2000. Crane and derricks, $3^{\text {rd }}$ edition, McGraw Hill, New York. pp-1-35.

[18] Vinay Dubey, Rajiv Premi- "Hazard Identification of cranes and their control measures". 2016 IJEDR | Volume 4, Issue 1 | ISSN: pp-2321-9939. 